\title{
Extinction of North American Cuvieronius (Mammalia: Proboscidea: Gomphotheriidae) driven by dietary resource competition with sympatric mammoths and mastodons
}

\author{
Gregory James Smith (D) and Larisa R. G. DeSantis (D)
}

\begin{abstract}
The gomphotheres were a diverse and widespread group of proboscideans occupying Eurasia, North America, and South America throughout the Neogene. Their decline was temporally and spatially heterogeneous, and the gomphotheres ultimately became extinct during the late Pleistocene; however, the genus Cuvieronius is rarely represented in late Pleistocene assemblages in North America. Two alternative hypotheses have been invoked to explain this phenomenon: (1) competitive exclusion by sympatric mammoths and mastodons or (2) ecologic displacement due to an environmental transition from closed forests to open grasslands. To test whether competition for resources contributed to the demise of North American Cuvieronius, we present herein a large collection of stable isotope and dental microwear data from populations occupying their Pleistocene refugium in the Atlantic Coastal Plain. Results suggest that Cuvieronius consumed a wide range of resources with variable textural and photosynthetic properties and was not specialized on either grasses or browse. Further, we document evidence for the consumption of similar foods between contemporaneous gomphotheres, mammoths, and mastodons. The generalist feeding strategy of the gomphotheres likely facilitated their high Miocene abundance and diversity. However, this "jack of all trades and master of none" feeding strategy may have proved challenging following the arrival of mammoths and likely contributed to the extirpation of Cuvieronius in North America.
\end{abstract}

Gregory James Smith. Department of Earth and Environmental Sciences, Vanderbilt University, Nashville, Tennessee 37240, U.S.A. E-mail: gxs258@gmail.com

Larisa R. G. DeSantis. Department of Biological Sciences, Vanderbilt University, Nashoille, Tennessee 37232, U.S.A.; and Department of Earth and Environmental Sciences, Vanderbilt University, Nashville, Tennessee 37240, U.S.A. E-mail: larisa.desantis@vanderbilt.edu

Accepted: 4 January 2020

Data available from the Dryad Digital Repository: https://doi.org/10.5061/dryad.6djh9w0x1

\section{Introduction}

Gomphotheres (subfamily Gomphotheriinae sensu lato) are temporally and spatially prolific; the clade became dominant in North America in the Miocene and emigrated to South America from North America after the closure of the Isthmus of Panama between 2.5 and 0.125 Ma (Webb 1985; Reguero et al. 2007; Woodburne 2010; Mothé et al. 2017). Their dietary flexibility is hypothesized to have facilitated their successful migration in contrast to mammoths and mastodons, which remained in Central and North America despite the continental connection (Pérez-Crespo et al. 2016). On the other hand, gomphothere abundance, diversity, and geographic range in North America rapidly drops off after the arrival of mammoths, and the gomphotheres are rarely represented in Rancholabrean faunal assemblages (ca. 0.3-0.012 Ma sensu Bell et al. 2004) (Carrasco et al. 2005). The success of the mammoth radiation and its temporal correlation with the demise of the gomphotheres in North America has led some to argue that competition from early mammoths caused the extirpation of the gomphotheres (i.e., competitive exclusion; Kurtén and Anderson 1980). However, others have argued that cooling climates and the emergence of steppe/prairie habitats would have displaced the gomphotheres from North America even in the absence of competition (i.e., ecological displacement; Dudley 1996). These two competing hypotheses have yet to be fully tested or resolved.

The competitive exclusion principle attests that when closely related species with similar niches coexist, one of these taxa will either outcompete the other or they will partition their 
niches to exploit different resources (Hardin 1960). Niche partitioning studies in fossil ungulates are commonly carried out through a reconstruction of diet using methods similar to those implemented here and often show the alteration of dietary preference by one or multiple organisms to facilitate coexistence with other organisms (e.g., in bovids, camelids, and horses; MacFadden et al. 1999; Bibi 2007; DeSantis et al. 2009; Yann and DeSantis 2014). Similarly, studies of proboscidean dietary niche partitioning often indicate high dietary flexibility among focal taxa (e.g., Calandra et al. 2008; Rivals et al. 2015; Pérez-Crespo et al. 2016). Most paleoecological studies on gomphotheres suggest that they were already highly flexible in their dietary choices, capable of fluctuating between grazing, browsing, and mixed-feeding habits (e.g., MacFadden and Cerling 1996; Koch et al. 1998, 2004; MacFadden 2000; Fox and Fisher 2001, 2004; Sánchez et al. 2004; Calandra et al. 2008; DeSantis et al. 2009; Rivals et al. 2015; Pérez-Crespo et al. 2016; Zhang et al. 2017; González-Guarda et al. 2018). However, on a smaller spatial and temporal scale, gomphotheres tended to restrict their dietary preferences due to abiotic (climatic) or biotic (competitive) factors; for example, South American populations of Notiomastodon showed an adaptive trend toward either grazing or browsing habits in the late Pleistocene due to habitat differentiation (Sánchez et al. 2004; Mothé and Avilla 2015), South China populations of Sinomastodon were restricted to the consumption of browse due to competition with co-occurring Stegodon (Zhang et al. 2017), and the East Asian gomphotherid Protanancus was competitively displaced by the amebelodont Platybelodon (Wang et al. 2015). Recognizing this pattern of dietary restriction in smaller populations, we therefore limit our analysis herein to Pleistocene populations of gomphothere (Cuvieronius hyodon), mammoth (Mammuthus columbi), and mastodon (Mammut americanum) occupying the Atlantic Coastal Plain (ACP) physiogeographic province of North America (Fig. 1A).

While both the mastodon and the gomphothere families were present in the ACP since the middle Miocene, the earliest mammoths did not arrive until the early Pleistocene
(Hulbert 2001). Mastodons, represented by the genus Zygolophodon, and gomphotheres, including the genus Gomphotherium, have been recovered from Miocene sites in both Florida and Texas (Lambert and Shoshani 1998). Later representatives of these clades, including the mastodon Mammut and the gomphothere Rhynchotherium, are found extensively in the southern latitudes of North America and Central America beginning in the early Pliocene (Lambert and Shoshani 1998; Lucas and Alvarado 2010; Pasenko 2012). Cuvieronius - the only gomphothere genus found in North America, South America, and Central America-appears in Florida by ca. 2 Ma (Arroyo-Cabrales et al. 2007; Lucas 2008; Lucas and Alvarado 2010). The mammoth specimens recovered from the ACP are coeval with some of the earliest Mammuthus records in North America from the Rio Grande valley of southern New Mexico (Lucas et al. 2017). Cuvieronius is known in Florida until ca. 0.5 Ma (Lucas 2008); however, some of the youngest Cuvieronius records known in North America come from the Big Cypress Creek site of east Texas (Lundelius et al. 2013, 2019). Mammuthus and Mammut are last known from North America in late Pleistocene sites between 14 and $10 \mathrm{ka}$ (Bell et al. 2004; Barnosky et al. 2014). Thus, the samples used in this study include some of the earliest and latest examples of these proboscidean taxa in the ACP.

This study aims to fill an important spatial and temporal gap in the paleoecological record of proboscideans. In this paper, we present a quantitative analysis of dietary differences among Pleistocene proboscideans in North America using the integration of stable isotope geochemistry and dental microwear texture analysis (DMTA). The design of this study allows for both a regional comparison over time (from the early to late Pleistocene) and local, site-based assessments. Specifically, multiproxy data are used to test the following hypotheses: (1) North American Cuvieronius consumed similar resources as sympatric Mammuthus and/or Mammut; and (2) Cuvieronius, Mammuthus, and Mammut altered their dietary habits in the ACP throughout the Pleistocene. Evidence for the consumption of similar resources by Cuvieronius and Mammuthus or 


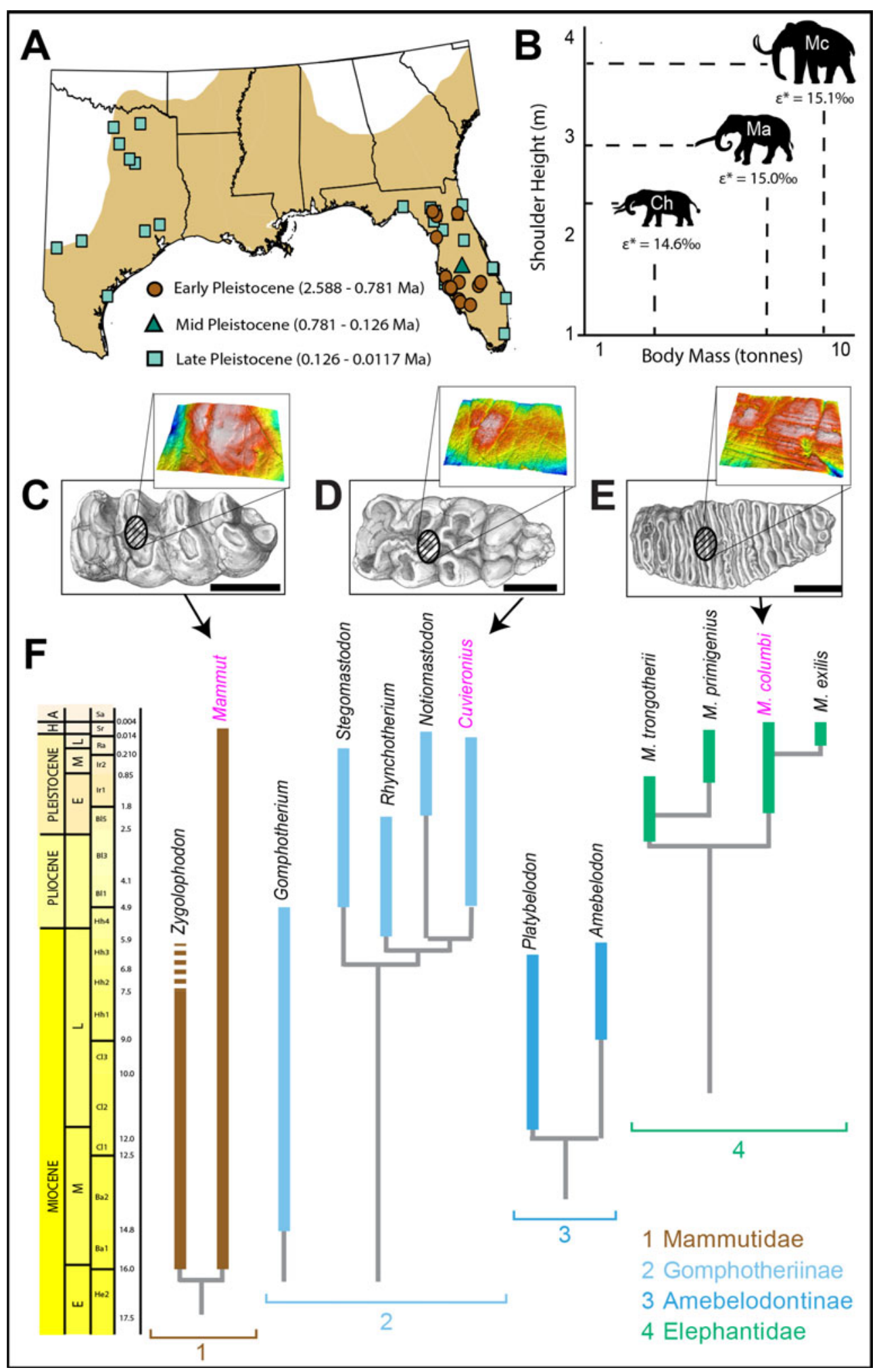


Mammut, as inferred via stable isotopes and dental microwear textures, may suggest that competition was a primary driver of the extirpation of North American gomphotheres.

\section{Materials and Methods}

Fossil Populations.-Our study uses specimens recovered from numerous fossil mammal sites in the ACP of the United States (Fig. 1A). We first compiled all published bulk stable isotope data (MacFadden and Cerling 1996; Koch et al. 1998; Feranac and MacFadden 2000; Hoppe 2004; Koch et al. 2004; DeSantis et al. 2009; Yann and DeSantis 2014; Yann et al. 2016; Smith and DeSantis 2018; Lundelius et al. 2019) and DMTA data previously analyzed on the confocal microscope located at Vanderbilt University (Green et al. 2017; Smith and DeSantis 2018) for proboscideans from this area (Supplementary Table 1). Focusing on localities from below $35^{\circ} \mathrm{N}$ limits the possible inclusion of $\mathrm{C}_{3}$ grass, which increases in abundance in more northern and western regions with decreased growing season temperatures (Teeri and Stowe 1976; Stowe and Teeri 1978; Still et al. 2003). All late Pleistocene samples in this study come from sites in east Texas and Florida. These regions likely had similar plant communities due to physiogeographic similarities; comparable precipitation amounts, mean annual temperatures, and moisture sources; and low abundances of $\mathrm{C}_{3}$ grasses and $\mathrm{C}_{4}$ shrubs, as reflected in ${ }^{13} \mathrm{C}$-enriched enamel in mammals from both regions. New targeted samples of primarily undersampled Cuvieronius and co-occurring Mammuthus and/or Mammut from the same locality were added to published data, resulting in a total of 248 bulk stable isotope samples and 241 DMTA samples.

Stable Isotope Geochemistry. - Geochemical bulk samples of the carbonate portion of enamel hydroxyapatite were removed from well-preserved proboscidean samples from the Texas Memorial Museum (TMM) in Austin, Texas, and the Florida Museum of Natural History (FLMNH) in Gainesville, Florida. All sampled teeth were drilled by hand using a variable-speed rotary drill with carbide dental burrs (1 mm burr width), which was used to create a $1 \mathrm{~cm} \times 1 \mathrm{~mm}$ sample transect oriented parallel to the growth axis of the tooth. Because sampling was not automated, the depth to which each sample was drilled varied, but was typically $\sim 1-2 \mathrm{~mm}$. Due to the nature of enamel growth in proboscidean teeth, this averages the dietary and environmental signal accrued in enamel tissue across multiple seasons (Dirks et al. 2012; Metcalfe and Longstaffe 2012). While prior work has shown that stable isotope values differ significantly in mammoth, mastodon, and gomphothere teeth due to seasonal changes in diet and environment (summarized in Metcalfe 2017), the use of large sample size for each time bin should overcome these deviations and better capture the average dietary tendencies in each organism.

The collected enamel powder was pretreated with $30 \% \mathrm{H}_{2} \mathrm{O}_{2}$ to remove organics, rinsed with distilled water, treated with $0.1 \mathrm{~N}$ acetic acid for 18 hours to remove secondary carbonates (similar to Koch et al. 1997), and rinsed with distilled water again. Samples were left to air dry, and $1 \mathrm{mg}$ per sample was analyzed on a VG Prism stable isotope ratio mass spectrometer with an in-line ISOCARB automatic sampler in the Department of Geological Sciences at the University of Florida. The standard deviation $(1 \sigma)$ of the laboratory standard included with these samples was $<0.05 \%$ for both carbon and oxygen. The analytical precision is $\pm 0.1 \%$, based on replicate analyses of samples and standards. Stable isotope data were normalized to NBS-19 and are reported in conventional delta notation.

FIGURE 1. Geography, body size, and phylogeny related to the study material. A, Overview of the study area, with the Atlantic Coastal Plain shaded (orange online) and sites delineated by their geologic ages. B, Average body size and shoulder height of the focal proboscideans with enrichment factor $\left(\varepsilon^{*}\right)$ obtained using body-size estimates. Ch, Cuvieronius hyodon; Ma, Mammut americanum; Mc, Mammuthus columbi. C, UF 80004, left m3. Scale bar, $10 \mathrm{~cm}$. Cross-hatching represents area where dental microwear texture analysis (DMTA) mold was sampled, with 3D surface model of wear facet (higherresolution images available in the Dryad repository for this manuscript). D, TMM 47200-172, right m3. E, UF 86825, right m1. F, Temporal ranges of North American proboscidean taxa (modified from Fisher 2018). Thick bars show known range of taxa; thin bars show uncertain range extensions. 
Stable carbon isotopes recorded in mammalian enamel reflect the photosynthetic signature of foods consumed (e.g., Cerling et al. 1997). Carbon values from enamel $\left(\delta^{13} \mathrm{C}_{\text {enamel }}\right)$ are reported relative to VPDB (Coplen 1994). Consumer $\delta^{13} C_{\text {enamel }}$ values were converted to the carbon isotope value of vegetation consumed $\left(\delta^{13} \mathrm{C}_{\mathrm{veg}}\right)$ using enrichment factors $\left(\varepsilon^{*}\right)$ of $15.1 \%$, $15.0 \%$, and $14.6 \%$ for Mammuthus columbi, Mammut americanum, and Cuvieronius hyodon, respectively. These enrichment factors were obtained using the regression equation for hindgut fermenters from Tejada-Lara et al. (2018): $\ln \varepsilon^{*}=2.42+0.032 *(B M)$, where $B M$ is body mass in kilograms and is logtransformed. Average body mass for each proboscidean taxon was derived from volumetric method estimates reported by Larramendi (2016); the body-mass values we used are $9500 \mathrm{~kg}$ for M. columbi, $8000 \mathrm{~kg}$ for M. americanum, and $3500 \mathrm{~kg}$ for C. hyodon (Fig. 1B). To correct for the effects of differing atmospheric carbon isotope $\left(\delta^{13} C_{a t m}\right)$ values over time on $\delta^{13} \mathrm{C}_{\text {veg }}$ values, we used estimates of past $\delta^{13} C_{\text {atm }}$ values from benthic foraminifera (Tipple et al. 2010) to convert paleodietary vegetation to their modern equivalent values $\left(\delta^{13} C_{v m e q}\right)$ based on an A.D. $2000 \delta^{13} C_{a t m}$ of $-8 \%$ (following methods outlined in Kohn 2010). Sample age came from site age estimates (see section on biochrons); we used the estimates of minimum and maximum site age (Supplementary Table 1) to calculate average $\delta^{13} \mathrm{C}_{\text {atm }}$ value over the age range of the sample. This value was inserted into eq. 3 from Kohn (2010) and used to calculate $\Delta$. We then calculated $\delta^{13} \mathrm{C}_{\mathrm{vmeq}}$ using the following linear regression equation, obtained using the data set in the supplemental material from Kohn (2010): $\delta^{13} C_{\text {vmeq }}=-0.9543 * \Delta-8.3617$. The $\delta^{13} C_{\text {vmeq }}$ values reported here reflect isotopic values of $\mathrm{C}_{3}$ shrubs/trees and $\mathrm{C}_{4}$ grasses, respectively, and are thus indicative of browsing, grazing, and mixed-feeding habits. Here we assume that $\delta^{13} \mathrm{C}_{\mathrm{vmeq}}$ values less than $-25.1 \%$ indicate diets of at least $85 \% \mathrm{C}_{3}$ vegetation while values greater than $-16.0 \%$ indicate at least $85 \% C_{4}$ vegetation; values in between suggest a mix of both $C_{3}$ and $C_{4}$ resources (Cerling et al. 1997; Kohn 2010; also see Supplementary Appendix 1).
Stable oxygen isotopes reflect environmental factors, including temperature and precipitation, and are useful for identifying spatially or temporally mixed assemblages or for separating glacial and interglacial periods. The oxygen isotopes reported here $\left(\delta^{18} \mathrm{O}_{\text {enamel }}\right)$ are those recorded in enamel and reflect multiple compounding factors impacting each individual proboscidean, including temperature, humidity, altitude, and latitude (Dansgaard 1964; also see Supplementary Appendix 1). Oxygen isotope values are reported relative to VSMOW. Previously published $\delta^{18} \mathrm{O}_{\text {enamel }}$ values reported relative to VPDB were converted using the following equation: $\delta^{18} \mathrm{O}_{\text {VSMOW }}=1.03086 * \delta^{18} \mathrm{O}_{\mathrm{VPDB}}+30.86$ (Friedman and O'Neil 1977).

Dental Microwear Texture Analysis.-Microwear molds were collected from the jaws and isolated teeth of proboscidean fossils held at TMM $(n=13)$ and FLMNH $(n=104)$. Sampling methods for DMTA followed procedures outlined in prior studies (Green et al. 2017; Smith and DeSantis 2018). Briefly summarized here, the wear facets of mammoth, mastodon, and gomphothere molars were cleaned with acetone and then sampled with Regular Body President's Jet to create a mold. We prioritized sampling the central enamel bands for all specimens (Fig. 1C-E) to maintain consistency with past studies of DMTA in proboscideans (Green et al. 2017; Zhang et al. 2017; Smith and DeSantis 2018) and because sampling these areas reduces the amount of variation in microwear features attributable to differences in the direction of the power stroke during mastication (e.g., Laub 1996; Todd et al. 2007; von Koenigswald 2016). The molds were then cast at Vanderbilt University using a high-resin epoxy (Epotek 301) and dried in a fume hood for at least 72 hours before analysis.

All specimens were scanned in three dimensions in four adjacent fields of view for a total sampled area of $204 \times 276 \mu \mathrm{m}^{2}$ using the Plu NEOX white-light microscope with confocal capabilities at Vanderbilt University. Scans were analyzed using scale-sensitive fractal analysis software (ToothFrax and SFrax, Surfract Corporation, www.surfract.com), which characterizes wear surfaces according to variables including complexity $(A s f c)$, anisotropy 
(epLsar), textural fill volume (Tfv), and heterogeneity of complexity $(H A s f c)$. Complexity is a quantification of the change in surface roughness with increasing scale and is used to distinguish taxa that consume hard/brittle foods from those that eat softer/tougher foods (Ungar et al. 2003, 2007; Scott et al. 2005; Prideaux et al. 2009; Scott 2012; DeSantis 2016). Anisotropy is the degree to which surface features share a similar orientation, such that a predominance of parallel striations leads toward highly anisotropic surfaces - typical in grazers and other consumers of tough food items (Ungar et al. 2003, 2007; Prideaux et al. 2009; Scott 2012; DeSantis 2016; Hedberg and DeSantis 2017). Textural fill volume is a measure of the total volume of square cuboids of a given scale that fill surface features and is useful for distinguishing deeper microwear features (such as gouges from pits), which has the potential to distinguish between consumption of foods with different fracture properties (e.g., leaves vs. fruit pits) (Scott et al. 2006; Ungar et al. 2007, 2008). Heterogeneity of complexity is calculated by splitting individual scanned areas into smaller sections with equal numbers of rows and columns (from $2 \times 2$ up to $11 \times 11$ ) and comparing $A s f c$ values between subregions (Scott et al. 2006). Low values in heterogeneity have been shown to be indicative of either high grit loads or grass consumption (Scott 2012; Merceron et al. 2016). We report heterogeneity at two scales, $3 \times 3\left(H_{A s f c_{3 \times 3}}\right)$ and $9 \times 9\left(H A s f c_{9 \times 9}\right)$, as has been the practice in previous studies (e.g., Green et al. 2017; Smith and DeSantis 2018).

Assignment to Biochronologic Intervals ("Biochrons").-Each proboscidean individual sampled for stable isotopes or DMTA was referred to a specific locality (Supplementary Table 1). For published samples, the minimum and maximum ages for that locality were inferred from the publication that contained the sample reference. For new samples, the age of the site was either determined from the literature or in consultation with the collections manager of the FLMNH (R. Hulbert personal communication 2019). DeSoto Shell Pit, Devil's Elbow, Haile 7C, and Brighton Canal were all considered to date to the late Blancan (B15). Following Lucas (2008), we consider all gomphotheriids from Florida from $\mathrm{Bl} 5$ or younger to be $C$. hyodon. We therefore include the samples originally referred to Rhynchotherium in MacFadden and Cerling (1996) and refer them to $C$. hyodon. Site ages were used to bin samples to the following biochrons, with ages from Bell et al. (2004): Bl5 (late Blancan), minimum age $=1.6 \mathrm{Ma}$, maximum age $=2.5$ Ma; Ir1 (early Irvingtonian), minimum age = $0.85 \mathrm{Ma}$, maximum age $=1.6 \mathrm{Ma}$; Ir2 (late Irvingtonian), minimum age $=0.3 \mathrm{Ma}$, maximum age $=0.85$; $\mathrm{Ra}$ (Rancholabrean), minimum age $=0.010 \mathrm{Ma}$, maximum age $=0.3 \mathrm{Ma}$.

Statistical Analyses.-All published and new data were combined for statistical comparisons. We carried out two statistical comparisons of $\delta^{13} \mathrm{C}_{\mathrm{vmeq}}, \delta^{18} \mathrm{O}_{\text {enamel, }}$ and DMTA attributes for each genus: first, within each biochron to test for consumption of similar foods in sympatric populations; and second, across biochrons to assess whether dietary niche was conserved over time for each taxon. Our tests for the late Pleistocene combined samples from Florida and east Texas based on the assumption that the paleoenvironment was broadly similar in the two regions at that time; however, we also excluded samples from Texas and reran statistical comparisons between $\delta^{13} C_{v m e q}$ and $\delta^{18} \mathrm{O}_{\text {enamel }}$ to ensure that this was a valid assumption. When comparing between normally distributed attributes, parametric tests (e.g., $t$-test or analysis of variance) were employed; otherwise, nonparametric equivalent tests (e.g., Mann-Whitney $U$ or KruskalWallis) were used. For all tests, the Bonferroni correction factor was withheld, as it can result in an increase in type II errors (Cabin and Mitchell 2000; Nakagawa 2004). p-Values of $<0.05$ were considered significant.

\section{Results}

Stable Isotope Ecology.-Mammut $\delta^{13} \mathrm{C}_{\mathrm{vmeq}}$ values are indistinguishable through time in contrast to Mammuthus, which exhibits higher $\delta^{13} \mathrm{C}_{\mathrm{vmeq}}$ values during the Rancholabrean as compared with the late Irvingtonian, and Cuvieronius, which has significantly lower mean $\delta^{13} C_{v m e q}$ values during the Rancholabrean than the early Irvingtonian (Table 1, all statistical comparisons in Supplementary 


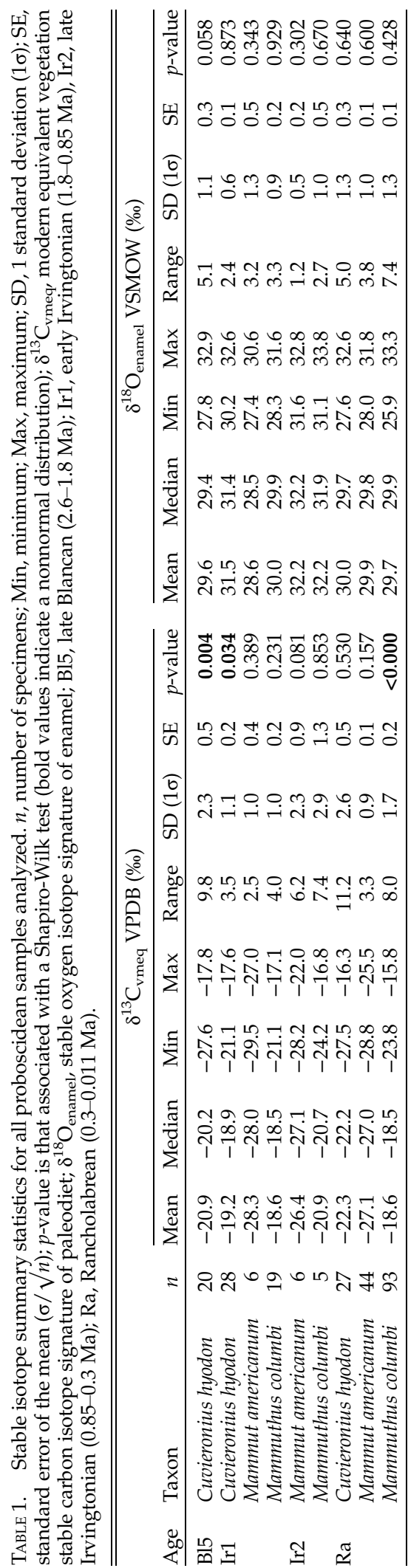

Table 2). Further, Mammut consistently has lower $\delta^{13} \mathrm{C}_{\mathrm{vmeq}}$ values than both Cuvieronius and Mammuthus through time, while Mammuthus has significantly greater $\delta^{13} \mathrm{C}_{\mathrm{vmeq}}$ values than Cuvieronius during the Rancholabrean (note, $\delta^{13} \mathrm{C}_{\mathrm{vmeq}}$ values are indistinguishable when compared with the early Irvingtonian values).

Oxygen isotope values of Cuvieronius are significantly greater during the early Irvingtonian than both the late Blancan and Rancholabrean (Table 1). In contrast, Mammut has significantly higher $\delta^{18} \mathrm{O}_{\text {enamel }}$ values during the late Irvingtonian than both the early Irvingtonian and Rancholabrean. Mammuthus has the highest $\delta^{18} \mathrm{O}_{\text {enamel }}$ values during the late Irvingtonian followed by the early Irvingtonian and Rancholabrean (all significantly different from one another, Supplementary Table 2). Overall, all proboscideans examined have indistinguishable $\delta^{18} \mathrm{O}_{\text {enamel }}$ values from one another during the late Irvingtonian and Rancholabrean, with only Cuvieronius yielding significantly higher $\delta^{18} \mathrm{O}_{\text {enamel }}$ values than both Mammut and Mammuthus during the early Irvingtonian.

Results are statistically unchanged when excluding Rancholabrean specimens from Texas from the analysis. The total range of $\delta^{13} \mathrm{C}_{\mathrm{vmeq}}$ values for Cuvieronius (11.2\%) and Mammuthus (8.0\%) during the Rancholabrean (Table 1$)$ remain similar $(10.0 \%$ and $7.3 \%$, respectively) after excluding specimens from Texas. When Texas specimens are excluded, the average $\delta^{13} C_{v m e q}$ value for Cuvieronius changes from $-22.3 \%$ to $-23.4 \%$, and the average $\delta^{13} \mathrm{C}_{\mathrm{vmeq}}$ value for Mammuthus changes from $-18.6 \%$ to $-20.7 \%$. Cuvieronius samples from Florida remain significantly lower in $\delta^{13} \mathrm{C}_{\mathrm{vmeq}}$ than Mammuthus samples from Florida $(p=0.001)$. Moreover, Rancholabrean Mammuthus and Cuvieronius $\delta^{18} \mathrm{O}_{\text {enamel values }}$ remain statistically indistinguishable from one another when Texas samples are removed $(p=0.072)$. In short, the results of this study hold whether looking at the ACP as a whole or at Florida alone.

Textural Properties of Food Resources. - Cuvieronius and Mammut both have Asfc, epLsar, Tfo, and $H A s f c\left(H A s f_{c} c_{3 \times 3}\right.$ and $\left.H A s f c_{9 \times 9}\right)$ values that are statistically indistinguishable within each taxon over time (Table 2, Supplementary 
TABLE 2. Dental microwear texture analysis (DMTA) summary statistics for all proboscideans analyzed, broken down by biochronologic interval. Asfc, area-scale fractal complexity; epLsar, anisotropy; Tfv, textural fill volume; $H A s f c_{3 \times 3}, H A s f c_{9 \times 9}$, heterogeneity of complexity in a $3 \times 3$ and $9 \times 9$ grid, respectively. See Table 1 for definitions of other abbreviations. Bold values indicate a nonnormal distribution (Shapiro-Wilk; $p<0.05$ is significant).

\begin{tabular}{|c|c|c|c|c|c|c|c|c|}
\hline Age & Taxon & $n$ & Statistic & $A s f c$ & epLsar & Tfo & $H A s f c_{3 \times 3}$ & $H A s f c_{9 \times 9}$ \\
\hline \multirow[t]{7}{*}{$\mathrm{B} 15$} & \multirow[t]{7}{*}{ Cuvieronius hyodon } & \multirow[t]{7}{*}{23} & Mean & 2.648 & 0.0028 & $11,033.23$ & 0.52 & 0.97 \\
\hline & & & Median & 1.799 & 0.0021 & $11,093.20$ & 0.46 & 0.88 \\
\hline & & & SD & 1.976 & 0.0018 & 2592.72 & 0.24 & 0.41 \\
\hline & & & Min & 0.734 & 0.0009 & 3848.99 & 0.16 & 0.37 \\
\hline & & & $\operatorname{Max}$ & 8.932 & 0.0070 & $15,524.80$ & 1.14 & 2.08 \\
\hline & & & Range & 8.198 & 0.0061 & $11,675.81$ & 0.98 & 1.71 \\
\hline & & & $p$ (normal) & $<0.001$ & $<0.001$ & 0.507 & 0.128 & 0.188 \\
\hline \multirow{21}{*}{ Ir1 } & \multirow{7}{*}{ Cuvieronius hyodon } & \multirow[t]{7}{*}{26} & Mean & 2.922 & 0.0033 & $11,542.25$ & 0.43 & 0.85 \\
\hline & & & Median & 2.383 & 0.0028 & 8558.31 & 0.39 & 0.76 \\
\hline & & & SD & 1.502 & 0.0018 & $10,073.70$ & 0.19 & 0.36 \\
\hline & & & Min & 0.980 & 0.0009 & 261.69 & 0.18 & 0.42 \\
\hline & & & Max & 6.863 & 0.0079 & $38,565.14$ & 1.15 & 2.06 \\
\hline & & & Range & 5.883 & 0.0070 & $38,303.45$ & 0.97 & 1.64 \\
\hline & & & $p$ (normal) & 0.006 & 0.009 & 0.006 & $<0.001$ & $<0.001$ \\
\hline & \multirow[t]{7}{*}{ Mammut americanum } & \multirow[t]{7}{*}{6} & Mean & 1.568 & 0.0040 & $20,116.41$ & 0.50 & 0.85 \\
\hline & & & Median & 1.806 & 0.0038 & $17,796.28$ & 0.36 & 0.56 \\
\hline & & & SD & 0.455 & 0.0016 & $13,445.93$ & 0.36 & 0.69 \\
\hline & & & Min & 0.736 & 0.0019 & 2165.10 & 0.19 & 0.39 \\
\hline & & & $\operatorname{Max}$ & 1.880 & 0.0067 & $35,814.78$ & 1.18 & 2.22 \\
\hline & & & Range & 1.144 & 0.0048 & $33,649.68$ & 0.99 & 1.83 \\
\hline & & & $p$ (normal) & 0.020 & 0.811 & 0.500 & 0.037 & 0.004 \\
\hline & \multirow[t]{7}{*}{ Mammuthus columbi } & \multirow[t]{7}{*}{28} & Mean & 2.165 & 0.0036 & $19,001.44$ & 0.41 & 0.68 \\
\hline & & & Median & 2.131 & 0.0034 & $18,913.25$ & 0.33 & 0.57 \\
\hline & & & SD & 0.988 & 0.0013 & $12,606.08$ & 0.26 & 0.37 \\
\hline & & & Min & 0.520 & 0.0012 & 544.26 & 0.17 & 0.34 \\
\hline & & & Max & 4.142 & 0.0071 & $55,980.02$ & 1.38 & 2.12 \\
\hline & & & Range & 3.622 & 0.0059 & $55,435.76$ & 1.21 & 1.78 \\
\hline & & & $p$ (normal) & 0.096 & 0.790 & 0.097 & $<0.001$ & $<0.001$ \\
\hline \multirow[t]{14}{*}{ Ir2 } & \multirow{7}{*}{ Mammut americanum } & \multirow[t]{7}{*}{5} & Mean & 2.243 & 0.0034 & $12,479.93$ & 0.38 & 0.72 \\
\hline & & & Median & 1.705 & 0.0029 & $12,061.95$ & 0.33 & 0.83 \\
\hline & & & SD & 1.361 & 0.0021 & 2037.17 & 0.16 & 0.30 \\
\hline & & & Min & 1.229 & 0.0014 & $10,630.75$ & 0.20 & 0.38 \\
\hline & & & $\operatorname{Max}$ & 4.588 & 0.0059 & $15,936.95$ & 0.56 & 1.02 \\
\hline & & & Range & 3.359 & 0.0045 & 5306.20 & 0.36 & 0.64 \\
\hline & & & $p$ (normal) & 0.062 & 0.295 & 0.157 & 0.299 & 0.236 \\
\hline & \multirow[t]{7}{*}{ Mammuthus columbi } & \multirow[t]{7}{*}{5} & Mean & 3.932 & 0.0027 & $11,479.5$ & 0.39 & 0.90 \\
\hline & & & Median & 3.317 & 0.0027 & $12,011.9$ & 0.38 & 0.92 \\
\hline & & & SD & 2.214 & 0.0017 & 2945.24 & 0.12 & 0.30 \\
\hline & & & Min & 1.863 & 0.0012 & 6672.06 & 0.26 & 0.54 \\
\hline & & & Max & 6.737 & 0.0054 & $14,755.22$ & 0.55 & 1.20 \\
\hline & & & Range & 4.874 & 0.0042 & 8083.16 & 0.29 & 0.66 \\
\hline & & & $p$ (normal) & 0.296 & 0.245 & 0.231 & 0.737 & 0.324 \\
\hline $\mathrm{Ra}$ & Cuvieronius hyodon & 23 & Mean & 2.227 & 0.0029 & 7691.2 & 0.44 & 0.57 \\
\hline & & & Median & 1.841 & 0.0027 & 9593.74 & 0.41 & 0.70 \\
\hline & & & $\mathrm{SD}$ & 1.389 & 0.0012 & 5242.24 & 0.21 & 0.40 \\
\hline & & & Min & 0.670 & 0.0010 & 181.28 & 0.17 & 0.39 \\
\hline & & & $\operatorname{Max}$ & 6.388 & 0.0054 & $17,000.26$ & 0.98 & 1.86 \\
\hline & & & Range & 5.718 & 0.0044 & $16,818.98$ & 0.81 & 1.47 \\
\hline & & & $p$ (normal) & 0.009 & 0.126 & 0.220 & 0.128 & 0.003 \\
\hline & Mammut americanum & 56 & Mean & 2.056 & 0.0037 & $10,082.39$ & 0.40 & 0.81 \\
\hline & & & Median & 1.403 & 0.0037 & $11,324.24$ & 0.35 & 0.62 \\
\hline & & & SD & 1.846 & 0.0018 & 3906.29 & 0.21 & 0.53 \\
\hline & & & Min & 0.032 & 0.0009 & 168.00 & 0.14 & 0.28 \\
\hline & & & Max & 11.717 & 0.0084 & $16,546.72$ & 0.99 & 3.05 \\
\hline & & & Range & 11.685 & 0.0075 & $16,378.72$ & 0.85 & 2.77 \\
\hline & & & $p$ (normal) & 0.062 & 0.295 & 0.157 & 0.299 & 0.236 \\
\hline & Mammuthus columbi & 69 & Mean & 2.503 & 0.0041 & $12,369.40$ & 0.41 & 0.75 \\
\hline & & & Median & 2.156 & 0.0041 & $12,209.77$ & 0.38 & 0.71 \\
\hline & & & SD & 1.387 & 0.0020 & 4737.62 & 0.22 & 0.33 \\
\hline
\end{tabular}


Table 2. Continued.

\begin{tabular}{|c|c|c|c|c|c|c|c|c|}
\hline Age & Taxon & $n$ & Statistic & $A s f c$ & epLsar & Tfo & $H A s f c_{3 \times 3}$ & $H A s f c_{9 \times 9}$ \\
\hline & & & Min & 0.456 & 0.0005 & 739.31 & 0.16 & 0.33 \\
\hline & & & Max & 6.471 & 0.0092 & $32,491.46$ & 1.66 & 2.10 \\
\hline & & & Range & 6.015 & 0.0087 & $31,752.15$ & 1.50 & 1.77 \\
\hline & & & $p$ (normal) & 0.001 & 0.101 & $<0.001$ & $<0.001$ & $<0.001$ \\
\hline
\end{tabular}

Table 2). Only Mammuthus exhibits significantly greater Tfv during the early Irvingtonian as compared with both the late Irvingtonian and Rancholabrean. During the early Irvingtonian, Cuvieronius has significantly higher $A s f_{C}$ values than Mammut, while Mammuthus has significantly higher Tfo than Cuvieronius. Mammut and Mammuthus have Asfc, epLsar, Tfv, and $H A s f c\left(H A s f_{3 \times 3}\right.$ and $\left.H A s f c_{9 \times 9}\right)$ values that are indistinguishable from one another during the late Irvingtonian. During the Rancholabrean, Mammuthus has significantly higher Asfc values than Mammut, Cuvieronius has significantly lower epLsar values than both Mammut and Mammuthus, and Mammuthus has significantly higher $T f o$ values than Cuvieronius and Mammut.

\section{Discussion}

Despite the oft-mentioned view that the extinction of gomphotheres was tied to competition with other megaherbivores, particularly mammoths (Kurtén and Anderson 1980; Cerling et al. 2003; Sanders 2007; Lucas et al. 2011; Lister 2013), there are few studies that have assessed competition between these taxa in the fossil record. Interspecific competition is notoriously difficult to verify when examining fossil populations, as paleoecologists can neither directly observe interference competition (e.g., male-male combat or other acts of aggression toward a competitor) nor precisely quantify the magnitude of resource limitation leading toward exploitative competition (e.g., consumption of similar resources by two potential competitors). Because of these limitations, evidence of interspecific competition in the fossil record is usually either modeled using phylogenetic hypotheses (e.g., Rabosky 2013) or inferred from character displacement (Schluter 2000; Grant and Grant 2006). However, the paleontological record offers a potential strength in documenting the signs of exploitative and interference competition over geologic timescales if one makes a few assumptions about how competition between megaherbivores could manifest in the fossil record. First, if one assumes via the principle of limiting similarity that there is a limit to how similar species can be and still coexist (MacArthur and Levins 1967; May and MacArthur 1972; May 1974), then it follows that there is an upper limit of shared niche space that would facilitate coexistence between two species. Above this limit, it becomes more likely that one species will exclude the other through competition for resources. Second, if one assumes that competition promotes the use of different resources (as opposed to complete exclusion) (Schoener 1974, 1982; Pianka 1976), then shifting dietary habits over geologic timescales may be correlated with the intensity of interspecific competition. In this case, demonstrating such shifts in response to the presence of a potential competitor can be considered evidence of competition (Pianka 1976). Finally, if we assume that where mammoths are abundant, they may be considered keystone competitors (sensu Bond 1993), then mammoths should limit large herbivore abundances via monopolizing resource utilization in their local communities (Fritz 1997; Fritz et al. 2002). Bearing these assumptions in mind, we elaborate below on the evidence for interspecific competition between sympatric megaherbivores in Pleistocene North America with relevance to the extirpation and eventual extinction of Cuvieronius.

Although we are unable at present to generalize beyond the southeastern United States, our results comprise two lines of evidence that support the competitive exclusion hypothesis (as opposed to the ecological displacement hypothesis [Dudley 1996]). First, data presented here support the hypothesis that Columbian mammoth (M. columbi) and gomphothere 
(C. hyodon) populations consumed foods of similar geochemical and textural properties during the early Irvingtonian (1.6-1.0 Ma), when mammoths first appear in North America. Specifically, mean $\delta^{13} \mathrm{C}_{\mathrm{vmeq}}$ values of $-19.2 \%$ and $-18.6 \%$ for Cuvieronius and Mammuthus, respectively, indicate a predominately $\mathrm{C}_{4}$ grazing signature supplemented with $\mathrm{C}_{3}$ resources (Table 1), while moderate Asfc and epLsar values that both have a high range similarly suggest a highly generalized mixedfeeding signature for both proboscideans (Table 2). All of these proxy data (i.e., $\delta^{13} \mathrm{C}_{\mathrm{vmeq}}$ $A s f c$, and epLsar) are statistically indistinguishable for gomphotheres and mammoths. We interpret these results to show that, upon arriving in the ACP, Mammuthus began to exploit similar resources as endemic Cuvieronius.

All early Irvingtonian samples in our data set come from two assemblages from Florida - the Leisey Shell Pit Local Fauna (LSPLF) (Morgan and Hulbert 1995) and the Punta Gorda Local Fauna (PGLF) (Webb 1974). The LSPLF was deposited during an interglacial period ca. 1.6-1.0 Ma, as supported by magnetic polarity dates; strontium isotope values on marine bivalves; stratigraphic evidence of a high-stage sea-level stand; vertebrate chronology, including the presence of warm-adapted vertebrates such as alligators; and ${ }^{18} \mathrm{O}$-enriched values in mammalian herbivore enamel, consistent with a drier climate (Morgan and Hulbert 1995; DeSantis et al. 2009). Our data show no statistically significant difference in $\delta^{18} \mathrm{O}_{\text {enamel values }}$ between LSPLF and PGLF Cuvieronius (mean $\delta^{18} \mathrm{O}_{\text {enamel }}=31.5 \%$ and $31.4 \%$, respectively; $p=0.867$ ) or Mammuthus (mean $\delta^{18} \mathrm{O}_{\text {enamel }}=$ $30.1 \%$ and $29.9 \%$, respectively; $p=0.534$ ). This may indicate that a similar climatic setting was experienced by both faunas, which would support the inference by Morgan and Hulbert (1995) that the two sites are of similar ages. DeSantis et al. (2009) reported significant differences in the $\delta^{13} \mathrm{C}$ signatures of browsers (Palaeolama, Tapirus, Mammut, Odocoileus), mixed feeders (Mylohyus, Platygonus, Hemiauchenia), and grazers (Equus, Mammuthus, Cuvieronius) of the LSPLF, but noted no significant differences when browsers were compared with one another or when grazers were compared with one another. The authors suggested that the high degree of niche partitioning among the mammalian community, facilitated by the abundance of $\mathrm{C}_{4}$ grass and the diversity of $\mathrm{C}_{3}$ dietary resources, may have contributed to the high mammalian diversity of the LSPLF (DeSantis et al. 2009). Our results corroborate this suggestion and specifically indicate that Cuvieronius and Mammuthus were able to coexist during the early Irvingtonian despite consuming foods of similar geochemical and textural properties. This suggests that there must have been an abundance of dietary resources in the ACP, as both proboscideans were large monogastriccaecalid grazers with high dietary resource intake requirements (Guthrie 1984). As large mammalian herbivores are primarily food limited (Sinclair 1975) (as opposed to predator limited [e.g., Sinclair et al. 2003; Fritz et al. 2011]), warm climates and long growing seasons likely produced a diverse floral habitat with considerable local heterogeneity needed to support such a high abundance of closely related and ecologically similar taxa (a "vegetative mosaic" [Guthrie 1984]).

The second line of evidence in support of the competitive exclusion hypothesis is niche plasticity in Cuvieronius populations occupying the ACP. While stable isotope and dental microwear data do support the hypothesis of shifting dietary habits over time, the magnitude and direction of this shift varies by taxon. Mammut exhibits the narrowest dietary niche of the three proboscideans, with the smallest range in $\delta^{13} C_{v m e q}$ values of all taxa in each NALMA (Table 1) and statistically unchanging DMTA attribute values for all NALMAs (Table 2, Supplementary Table 2). Further, Mammut $\delta^{13} \mathrm{C}_{\mathrm{vmeq}}$ values are consistently significantly lower than either Cuvieronius or Mammuthus values, implying a persistent preference for $C_{3}$ dietary resources over time - interpreted here as woody-browse. Because of the high abundance of Mammut remains recovered in the $\mathrm{ACP}$, our interpretation of these data is that mastodons successfully dominated the "large monogastric browser" niche up until the endPleistocene, even during periods of resource limitation. Similarly, Mammuthus $\delta^{13} \mathrm{C}_{\mathrm{vmeq}}$ $A s f c$, and epLsar values do not change significantly from the early Irvingtonian to the Rancholabrean, suggesting a similar dietary niche 
of $\mathrm{C}_{4}$ grazing supplemented with $\mathrm{C}_{3}$ resources of varying textural properties; thus, mammoths are interpreted as having occupied the "large monogastric grazer" niche. Because mammoths lacked a rumen (and could therefore not avoid absorbing toxic plant defenses including alkaloids and cyanogens into the bloodstream [Guthrie 1984]), they likely would have required a diet consisting of grass as a staple and supplemented by other plant species with complementary nutrients and less toxic defenses. In contrast to mammoths and mastodons, Cuvieronius populations show a statistically significant decrease in $\delta^{13} \mathrm{C}_{\mathrm{vmeq}}$ values from the early Irvingtonian to the Rancholabrean while more than doubling the standard deviation of mean $\delta^{13} C_{v m e q}$ values (Table 1). During the Rancholabrean, Cuvieronius populations in the ACP consumed a diet that was geochemically intermediate between Mammut and Mammuthus diets and texturally indistinguishable from either (Fig. 2). Rancholabrean gomphothere $\delta^{13} \mathrm{C}_{\mathrm{vmeq}}$ values are statistically equitable to their late Blancan $\delta^{13} C_{v m e q}$ values. Our interpretation of these data is that late Pleistocene gomphotheres in the $\mathrm{ACP}$ were mixed-feeding $\mathrm{C}_{3} / \mathrm{C}_{4}$ generalists (similar to gomphotheres in the early Pleistocene, before the arrival of mammoths), covering a dietary spectrum that was overlapped by mammoths on the grazing end and mastodons on the browsing end.

During the Pleistocene, rapid climate changes may have disturbed vegetative mosaics and led to floral community restructuring, resulting in periodic resource scarcity and affecting niche partitioning among large mammalian herbivores. Pleistocene glacialinterglacial dynamics became especially pronounced beginning ca. 70-60 ka, with the onset of 2-3 kyr warm-cool oscillations (Dansgaard-Oescher, or D-O, events) punctuated by abrupt ( $1 \mathrm{kyr})$ cool phases characterized by Heinrich events (i.e., the fracturing of ice shelves into the North Atlantic) (Heinrich 1988; Dansgaard et al. 1993; Bond and Lotti 1995; Elliot et al. 1998; Alley et al. 2003). These climatic changes likely led to phenological shifts in plant communities (e.g., earlier flowering or emergence dates) and individualistic shifts in the reproductive habits and geographic ranges of mammals, as is currently occurring in modern biotas (Graham 2005; Post 2013). Further, there is evidence from an $\sim 60$ kyr palynological record from south Florida that ACP pollen changes and the warming effects of D-O events were out of sync with the rest of North America (Grimm et al. 1993, 2006; Arnold et al. 2018). Heterogeneous climatic and environmental changes in North America served to break down the Pleistocene vegetative mosaics that had supported the coevolution of a high diversity of specialized groups of organisms (Graham and Lundelius 1984; Graham and Grimm 1990). As seasonal mixed feeders, proboscideans depend on the right composition of low-quality grass and high-quality (but chemically defended) browse emerging at the right time of year (e.g., Janzen and Martin 1982; Guthrie 1984; Owen-Smith 1988; Teale and Miller 2012; Metcalfe 2017); disruption of this timing would have limited the abundance of these dietary resources at critical times, potentially leading to increased intraand interspecific competition.

The large body size of mammoths and mastodons may have provided these taxa with a competitive advantage over sympatric gomphotheres. Cuvieronius hyodon was the smallest of the three proboscidean taxa in the $\mathrm{ACP}$ - on average, between $57 \%$ and $68 \%$ less massive than M. columbi and $48 \%$ to $62 \%$ less massive than Mammut based on volumetric estimates of body mass (Larramendi 2016). Mammut and Mammuthus were also considerably higher at the shoulder than Cuvieronius (Fig. 1B) (Larramendi 2016). As a result, gomphothere populations were more likely to suffer from both interference competition and exploitative competition with mammoths and mastodons. Modern African elephants (Loxodonta africana) are known to aggressively attack and kill smaller large herbivores such as rhinoceroses, particularly when adult males enter musth (a periodic condition characterized by a sharp rise in aggressive behavior, temporin secretion, and the continuous discharge of urine) (Poole 1987; Berger and Cunningham 1998; Slotow and van Dyk 2001). Mammoths and mastodons likely engaged in similar violence; fossil evidence of the kind of male-on-male violence typical of musth includes two bull mammoths that 

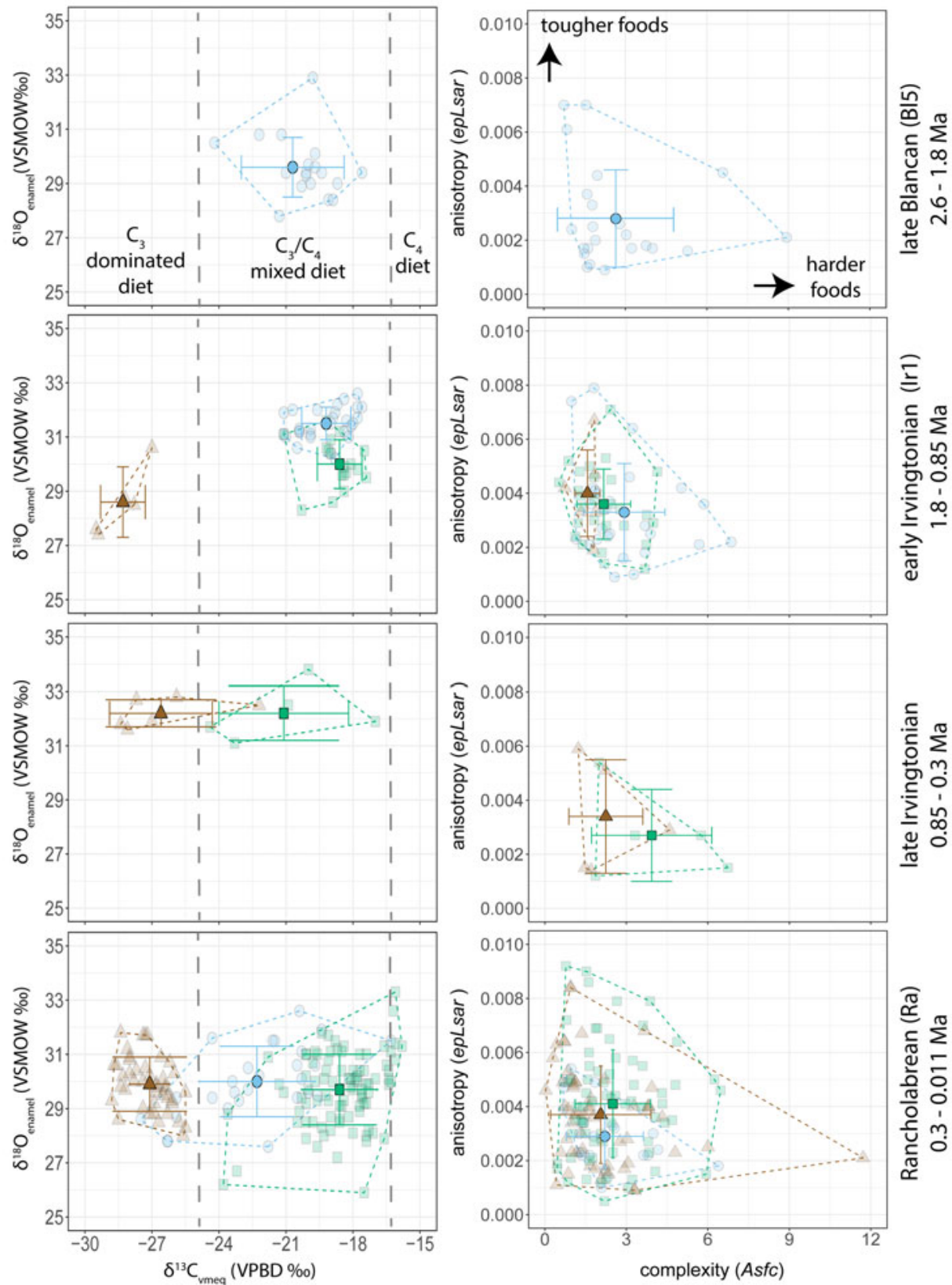

O Cuvieronius hyodon

$\Delta$ Mammut americanum

Mammuthus columbi

FIGURE 2. Bivariate plots of stable isotope values and dental microwear attributes for proboscidean samples from the Atlantic Coastal Plain. Circles (blue online), Cuvieronius hyodon; triangles (brown online), Mammut americanum; squares (green online), Mammuthus columbi. Mean values for each population are shown with error bars for the standard deviation; individual sample values are slightly transparent. Convex hulls overlay the range of values for each taxon.

died after their tusks became locked during combat (Agenbroad and Mead 1994) and pathologies on the mandible of the holotype of the Pacific mastodon (Mammut pacificus [Dooley et al. 2019]) consistent with tusk strikes from another bull. Additionally, low rates of dentin apposition in the tusks of mammoths in the Great Lakes and southern California suggest 
that some males regularly fasted, as modern elephants do during musth (Fisher 2004; El Adli et al. 2015). Exploitative competition was also likely; assuming dietary intake scales with body mass at a rate of $\mathrm{BM}^{0.75}$ (according to the Jarman-Bell principle [Geist 1974]), Mammuthus and Mammut would have consumed significantly more food than Cuvieronius. Using regression equations based on modern herbivores (Müller et al. 2013) and body-mass estimates from Larramendi (2016), we estimate that Mammuthus and Mammut consumed roughly twice as much dry matter per day as Cuvieronius $(49.9 \pm 4.5 \mathrm{~kg} /$ day and $43.7 \pm 4.9$ $\mathrm{kg} /$ day for Mammuthus and Mammut, respectively, as compared with $\sim 23.3 \mathrm{~kg} /$ day in Cuvieronius). This may have created food scarcity during resource-limited intervals if mammoth and mastodon abundances remained high; for example, modern African elephants with large population densities have been shown to impact the foraging patterns of black rhinoceroses (Diceros bicornis), with rhinos switching from a diet composed of mostly browse to one consisting of mostly grass during seasons of resource scarcity, when elephants have monopolized their food sources (Landman et al. 2013). This reduced intake of preferred foods and change in diet along the grass-browse continuum may have reduced gomphothere diet quality, causing reduced body mass and/or reduced fecundity (as has been shown to occur in modern ungulates [Simard et al. 2008; Christianson and Creel 2009]).

\section{Conclusions}

In conclusion, dietary proxy data from proboscideans indicate that the early Pleistocene coexistence of mammoths and gomphotheres was potentially made possible by both proboscideans exhibiting a generalist mixed-feeding dietary habit permitted by abundant resources, but that dramatic climatic and ecologic changes in the late Pleistocene may have limited resource availability and led to increased interspecific competition. Gomphotheres were part of a highly coevolved ecological food web that began to experience disruption due to dramatic climatic and ecologic changes in the Pleistocene. The results of this study demonstrate that competition between mammoths, mastodons, and the gomphothere Cuvieronius was prevalent in the ACP of North America throughout the Pleistocene. Cuvieronius may have migrated into South America in the late Pleistocene tracking a preferred environmental habitat (Mothé et al. 2017), but populations in the ACP of North America experienced heavy competition with Mammuthus and Mammut before disappearing entirely. Using multiple dietary proxies from sympatric megaherbivores, interspecific interactions including niche partitioning and competition can be inferred and here provide compelling evidence for gomphotheres being competitively excluded in North America during the late Pleistocene megafaunal extinctions.

\section{Acknowledgments}

Funding included a Geological Society of America student research grant, the Paleontological Society Stephen Jay Gould Award, and the Theodore Roosevelt Memorial Fund to G.J.S., as well as National Science Foundation grant no. 1053839 and Vanderbilt University funds to L.R.G.D. We thank the collections managers and curators of the Texas Memorial Museum and the Florida Museum of Natural History for access to and assistance with the collections, especially R. Hulbert, E. Lundelius, and C. Sagebiel. B. Engh sketched the molars in Figure 1, and J. Curtis analyzed new stable isotope samples at the University of Florida. Thanks to D. Mothé, J. El Adli, and V. A. Pérez-Crespo for providing helpful reviews that greatly improved this article.

\section{Literature Cited}

Agenbroad, L. D., and J. I. Mead. 1994. The Hot Springs Mammoth Site: a decade of field and laboratory research in the paleontology, geology, and paleoecology. Mammoth Site of South Dakota, Inc., Hot Springs, S.Dak.

Alley, R. B., J. Marotzke, W. D. Nordhaus, J. T. Overpeck, D. M. Peteet, R. A. Pielke, R. T. Pierrehumbert, P. B. Rhines, T. F. Stocker, L. D. Talley, and J. M. Wallace. 2003. Abrupt climate change. Science 299:2005-2010.

Arnold, T. E., A. F. Diefendorf, M. Brenner, K. H. Freeman, and A. A. Baczynski. 2018. Climate response of the Florida peninsula to Heinrich events in the North Atlantic. Quaternary Science Reviews 194:1-11.

Arroyo-Cabrales, J., O. J. Polaco, C. Laurito, E. Johnson, M. T. Alberdi, and A. L. V. Zarmora. 2007. The proboscideans (Mammalian) of Mesoamerica. Quaternary International 169-170:17-23. 
Barnosky, A. D., M. Holmes, R. Kirchholtes, E. Lindsey, K. C. Maguire, A. W. Poust, M. A. Stegner, J. Sunseri, B. Swartz, J. Swift, N. A. Villavicencio, and G. O. U. Wogan. 2014. Prelude to the Anthropocene: two new North American Land Mammal Ages (NALMAs). Anthropocene Review 1:225-242.

Bell, C. J., E. L. Lundelius, A. D. Barnosky, R. W. Graham, and E. H. Lindsay. 2004. The Blancan, Irvingtonian, and Rancholabrean mammal ages. Pp. 232-314 in M.O. Woodburne, ed. Late Cretaceous and Cenozoic mammals of North America: biostratigraphy and geochronology. Columbia University Press, New York.

Berger, J., and C. Cunningham. 1998. Behavioural ecology in managed reserves: gender-based asymmetries in interspecific dominance in African elephants and rhinos. Animal Conservation 1:33-38.

Bibi, F. 2007. Dietary niche partitioning among fossil bovids in late Miocene $C_{3}$ habitats: consilience of functional morphology and stable isotope analysis. Palaeogeography, Palaeoclimatology, Palaeoecology 253:529-538.

Bond, G. C., and R. Lotti. 1995. Iceberg discharges into the North Atlantic on millennial time scales during the last glaciation. Science 267:1005-1010.

Bond, W. J. 1993. Keystone species. Pp. 237-253 in E.D. Schulze and H.A. Mooney, eds. Biodiversity and ecosystem function. Springer, Berlin.

Cabin, R. J., and R. J. Mitchell. 2000. To Bonferroni or not to Bonferroni: when and how are the questions. Bulletin of the Ecological Society of America 81:246-248.

Calandra, I., U. B. Göhlich, and G. Merceron. 2008. How could sympatric megaherbivores coexist? Example of niche partitioning within a proboscidean community from the Miocene of Europe. Naturwissenschaften 95:831-838.

Carrasco, M. A., B. P. Kraatz, E. B. Davis, and A. D. Barnosky. 2005. Miocene Mammal Mapping Project (MIOMAP). University of California Museum of Paleontology, Berkeley. https://ucmp. berkeley.edu/miomap, accessed 19 May 2019.

Cerling, T. E., J. M. Harris, B. J. MacFadden, M. G. Leakey, J. Quade, V. Eisenmann, and J. R. Ehleringer. 1997. Global vegetation change through the Miocene/Pliocene boundary. Nature 389:153-158.

Cerling, T. E., J. M. Harris, and M. G. Leakey. 2003. Isotope paleoecology of the Nawata and Nachukui Formations at Lothagam, Turkana Basin, Kenya. Pp. 605-624 in M. G. Leakey and J. M. Harris, eds. Lothagam: the dawn of humanity in eastern Africa. Columbia University Press, New York.

Christianson, D., and S. Creel. 2009. Effects of grass and browse consumption on the winter mass dynamics of elk. Oecologia 158:603-613.

Coplen, T. B. 1994. Reporting of stable hydrogen, carbon, and oxygen isotopic abundances. Pure and Applied Chemistry 66:273-276

Dansgaard, W. 1964. Stable isotopes in precipitation. Tellus 16:273276.

Dansgaard, W., S. J. Johnsen, H. B. Clausen, D. Dahl-Jensen, N. S. Gundenstrup, C. U. Hammer, C. S. Hvidberg, J. P. Steffensen, A. E. Sveinbjörnsdottir, J. Jouzel, and G. Bond. 1993. Evidence for general instability of past climate from a 250 kyr ice-core record. Nature 364:218-220.

DeSantis, L. R. G. 2016. Dental microwear textures: reconstructing diets of fossil mammals. Surface Topography: Metrology and Properties 4:1-12.

DeSantis, L. R. G., R. S. Feranec, and B. J. MacFadden. 2009. Effects of global warming on ancient mammalian communities and their environments. PLoS ONE 4(6):e5750. https://doi.org/10.1371/ journal.pone.0005750.

Dirks, W., T. G. Bromage, and L. D. Agenbroad. 2012. The duration and rate of molar plate formation in Palaeoloxodon cypriotes and
Mammuthus columbi from dental histology. Quaternary International 255:79-85.

Dooley, A. C., E. Scott, J. L. Green, K. B. Springer, B. S. Dooley, and G. J. Smith. 2019. Mammut pacificus sp. nov., a newly recognized species of mastodon from the Pleistocene of western North America. Peerj 7:e6614. https://doi.org/10.7717/peerj.6614.

Dudley, J. P. 1996. Mammoths, gomphotheres, and the Great American Faunal Interchange. Pp. 289-295 in J. Shoshani and P. Tassy, eds. The Proboscidea: evolution and paleoecology of elephants and their relatives. Oxford University Press, New York.

El Adli, J. J., M. D. Cherney, D. C. Fisher, J. M. Harris, A. B. Farrell, and S. M. Cox. 2015. Last years of life and season of death of a Columbian mammoth from Rancho La Brea. Natural History Museum of Los Angeles County Science Series 42:65-80.

Elliot, M., L. Labeyrie, G. Bond, E. Cortijo, J. L. Turon, N. Tisnerat, and J. C. Duplessy. 1998. Millennial-scale iceberg discharges in the Irminger Basin during the last glacial period: relationship with the Heinrich events and environmental settings. Paleoceanography 13:433-446.

Feranac, R. S., and B. J. MacFadden. 2000. Evolution of the grazing niche in Pleistocene mammals from Florida: evidence from stable isotopes. Palaeogeography, Palaeoclimatology, Palaeoecology 162:155-169.

Fisher, D. C. 2004. Season of musth and musth-related mortality in Pleistocene mammoths. Journal of Vertebrate Paleontology 24 (Suppl. to No. 003):58A.

Fisher, D. C. 2018. Paleobiology of Pleistocene Proboscideans. Annual Review of Earth and Planetary Sciences 46:229-260.

Fox, D. L., and D. C. Fisher. 2001. Stable isotope ecology of a Late Miocene population of Gomphotherium productus (Mammalia, Proboscidea) from Port of Entry Pit, Oklahoma, USA. Palaios 16:279-293.

Fox, D. L., and D. C. Fisher. 2004. Dietary reconstruction of Miocene Gomphotherium (Mammalia, Proboscidea) from the Great Plains region, USA, based on the carbon isotope composition of tusk and molar enamel. Paleogeography, Paleoclimatology, Paleoecology 206:311-335.

Friedman, I., and J. R. O'Neil. 1977. Compilation of stable isotope fractionation factors of geochemical interest. Professional Paper 440- KK. U.S. Government Printing Office, Washington, D.C. https://doi.org/10.3133/pp440KK.

Fritz, H. 1997. Low ungulate biomass in west African savannas: primary production or missing megaherbivores or large predator species? Ecography 20:417-421.

Fritz, H., P. Duncan, I. J. Gordon, and A. W. Illius. 2002. Megaherbivores influence trophic guilds structure in African ungulate communities. Oecologia 131:620-625.

Fritz, H., M. Loreau, S. Chamaille-Jammes, M. Valeix, and J. Clobert. 2011. A food web perspective on large herbivore community limitation. Ecography 34:196-202.

Geist, V. 1974. On the relationship of social evolution and ecology in ungulates. American Zoologist 14:205-220.

González-Guarda, E., A. Petermann-Pichincura, C. Tornero, L. Domingo, J. Agustí, M. Pino, A. M. Abarzúa, J. M. Capriles, N.A. Villavicencio, R. Labarca, V. Tolorza, P. Sevilla, and F. Rivals. 2018. Multiproxy evidence for leaf-browsing and closed habitats in extinct proboscideans (Mammalia, Proboscidea) from Central Chile. Proceedings of the National Academy of Sciences USA 115(37):9258-9263.

Graham, R. W. 2005. Quaternary mammal communities: relevance of the individualistic response and non-analogue faunas. Paleontological Society Papers 11:141-158.

Graham, R. W., and E. C. Grimm. 1990. Effects of global climate change on the patterns of terrestrial biological communities. Trends in Ecology and Evolution 5:289-292.

Graham, R. W., and E. L. Lundelius. 1984. Coevolutionary disequilibrium and Pleistocene extinctions. Pp. 223-249 in P. S. Martin 
and R. G. Klein, eds. Quaternary extinctions: a prehistoric revolution. University of Arizona Press, Tuscon.

Grant, P. R., and B. R. Grant. 2006. Evolution of character displacement in Darwin's finches. Science 313:224-226.

Green, J. L., L. R. G. DeSantis, and G. J. Smith. 2017. Regional variation in the browsing diet of Pleistocene Mammut americanum (Mammalia, Proboscidea). Palaeogeography, Palaeoclimatology, Palaeoecology 487:59-70.

Grimm, E. C., G. L. Jacobson, W. A. Watts, B. C. S. Hansen, and K. A. Maasch. 1993. A 50,000-year record of climate oscillations from Florida and its temporal correlation with the Heinrich events. Science 261:198-200.

Grimm, E. C., W. A. Watts, G. L. Jacobson, B. C. S. Hansen, H. R. Almquist, and A. C. Diffenbacher-Krall. 2006. Evidence for warm wet Heinrich events in Florida. Quaternary Science Reviews 25:2197-2211.

Guthrie, R. D. 1984. Mosaics, allelochemics and nutrients: an ecological theory of Late Pleistocene Megafaunal Extinctions. Pp. 259-298 in P. S. Martin and R. G. Klein, eds. Quaternary extinctions: a prehistoric revolution. University of Arizona Press, Tuscon.

Hardin, G. 1960. The competitive exclusion principle. Science 131:1292-1297.

Hedberg, C., and L. R. G. DeSantis. 2017. Dental microwear texture analysis of extant koalas: clarifying causal agents of microwear. Journal of Zoology 301:206-214.

Heinrich, H. 1988. Origin and consequences of ice-rafting in the northeast Atlantic Ocean during the last 130,000 years. Quaternary Research 29:142-152.

Hoppe, K. A. 2004. Late Pleistocene mammoth herd structure, migration patterns, and Clovis hunting strategies inferred from isotopic analyses of multiple death assemblages. Paleobiology 30:129-145.

Hulbert, R. C., Jr. 2001. Mammalia 7: Proboscideans. Pp. 307-321 in R. C. Hulbert Jr., ed. The fossil vertebrates of Florida. University Press of Florida, Gainesville.

Janzen, D. H., and P. S. Martin. 1982. Neotropical anachronisms: the fruits the gomphotheres ate. Science 215:19-27.

Koch, P. L., N. Tuross, and M. L. Fogel. 1997. The effects of sample treatment and diagenesis on the isotopic integrity of carbonate in biogenic hydroxylapatite. Journal of Archaeological Sciences 24:417-429.

Koch P. L., K. A. Hoppe, and S. D. Webb. 1998. The isotope ecology of late Pleistocene mammals in North America, Part 1. Florida. Chemical Geology 152:119-138.

Koch, P. L., N. S. Diffenbaugh, and K. A. Hoppe. 2004. The effects of late Quaternary climate and $\mathrm{pCO} 2$ change on $\mathrm{C}_{4}$ plant abundance in the south-central United States. Palaeogeography, Palaeoclimatology, Palaeoecology 207:331-357.

Kohn, M. J. 2010. Carbon isotope compositions of terrestrial $C_{3}$ plants as indicators of (paleo)ecology and (paleo)climate. Proceedings of the National Academy of Sciences USA 107:1969119695.

Kurtén, B., and E. Anderson. 1980. Pleistocene mammals of North America. Columbia University Press, New York.

Lambert, D. W., and J. Shoshani. 1998. Proboscidea. Pp. 606-621 in C. Janis, K. Scott, and L. L. Jacobs, eds. Evolution of Tertiary mammals of North America, Vol. 1. Terrestrial carnivores, ungulates, and ungulate-like mammals. Cambridge University Press, New York.

Landman, M., D. S. Schoeman, and G. I. H. Kerley. 2013. Shift in black rhinoceros diet in the presence of elephant: evidence for competition? PLoS ONE 8(7):e69771. https://doi.org/10.1371/ journal.pone.0069771

Larramendi, A. 2016. Shoulder height, body mass, and shape of proboscideans. Acta Paleontologica Polonica 61:537-574.

Laub, R. S. 1996. The masticatory apparatus of the American mastodon (Mammut americanum). Pp. 375-405 in K. M. Stewart and K.
L. Seymour, eds. Palaeoecology and palaeoenvironments of Late Cenozoic Mammals: tributes to the career of C. S. (Rufus) Churcher. University of Toronto Press, Toronto.

Lister, A. M. 2013. The role of behaviour in adaptive morphological evolution of African proboscideans. Nature 500:331-334.

Lucas, S. G. 2008. Taxonomic nomenclature of Cuvieronius and Haplomastodon, proboscideans from the Plio-Pleistocene of the new world. New Mexico Museum Natural History and Science 44:409-415.

Lucas, S. G., and G. E. Alvarado. 2010. Fossil proboscidea from the upper Cenozoic of Central America: taxonomy, evolutionary and paleobiogeographic significance. Revista Geológica de América Central 42:9-42.

Lucas, S. G., R. H. Aguilar, and J. A. Spielmann. 2011. Stegomastodon (Mammalia, Proboscidea) from the Pliocene of Jalisco, Mexico and the species-level taxonomy of Stegomastodon. New Mexico Museum Natural History and Science 53:517-553.

Lucas, S. G., G. S. Morgan, D. W. Love, and S. D. Connell. 2017. The first North American mammoths: taxonomy and chronology of early Irvingtonian (early Pleistocene) Mammuthus from New Mexico. Quaternary International 443:2-13.

Lundelius, E. L., V. M. Bryant, R. Mandel, K. J. Thies, and A. Thomas. 2013. The first occurrence of a toxodont (Mammalia, Notoungulata) in the United States. Journal of Vertebrate Paleontology 33:229-232.

Lundelius, E. L., K. J. Thies, R. W. Graham, C. J. Bell, G. J. Smith, and L. R. G. DeSantis. 2019. Proboscidea from the Big Cypress Creek fauna, Deweyville Formation, Harris County, Texas. Quaternary International 530-531:59-68.

MacArthur, R., and R. Levins. 1967. The limiting similarity, convergence, and divergence of coexisting species. American Naturalist 101:377-385.

MacFadden, B. J. 2000. Middle Pleistocene climate change recorded in fossil mammal teeth from Tarija, Bolivia, and upper limit of the Ensenadan Land-Mammal Age. Quaternary Research 54:121-131.

MacFadden, B. J., and T. E. Cerling. 1996. Mammalian herbivore communities, ancient feeding ecology, and carbon isotopes: a 10-million year sequence from the Neogene of Florida. Journal of Vertebrate Paleontology 16:103-115.

MacFadden, B. J., N. Solounas, and T. E. Cerling. 1999. Ancient diets, ecology, and extinction of 5-million-year-old horses from Florida. Science 283:824-827.

May, R. M. 1974. On the theory of niche overlap. Theoretical Population Biology 5:297-332.

May, R. M., and R. H. MacArthur. 1972. Niche overlap as a function of environmental variability. Proceedings of the National Academy of Sciences USA 69:1109-1113.

Merceron, G., A. Ramdarshan, C. Blondel, J. R. Boisserie, N. Brunetiere, A. Francisco, D. Gautier, X. Milhet, A. Novello, and D. Pret. 2016. Untangling the environmental from the dietary: dust does not matter. Proceedings of the Royal Society of London B 283:20161032. https://doi.org/10.1098/rspb.2016.1032.

Metcalfe, J. Z. 2017. Proboscidean isotopic compositions provide insight into ancient humans and their environments. Quaternary International 443:147-159.

Metcalfe, J. Z., and F. J. Longstaffe. 2012. Mammoth tooth enamel growth rates inferred from stable isotope analysis and histology. Quaternary Research 77:424-432.

Morgan, G. S., and R. C. Hulbert. 1995. Overview of the geology and vertebrate biochronology of the Leisey Shell Pit local fauna, Hillsborough County, Florida. Bulletin of the Florida Museum of Natural History 37:1-92.

Mothé, D., and L. S. Avilla. 2015. Mythbusting evolutionary issues on South American Gomphotheriidae (Mammalia: Proboscidea). Quaternary Science Reviews 110:23-35.

Mothé, D., L. S. Avilla, L. Asevedo, L. Borges-Silva, M. Rosas, R. Labarca-Encina, R. Souberlich, E. Soibelzon, J. 
L. Roman-Carrion, S. D. Ríos, A. D. Rincon, G. C. Oliveira, and R. P. Lopes. 2017. Sixty years after "The mastodonts of Brazil": the state of the art of South American proboscideans (Proboscidea, Gomphotheriidae). Quaternary International 43:52-64.

Müller, D. W. H., D. Codron, C. Meloro, A. Munn, A. Schwarm, J. Hummel, and M. Clauss. 2013. Assessing the Jarman-Bell principle: scaling of intake, digestibility, retention time and gut fill with body mass in mammalian herbivores. Comparative Biochemistry and Physiology A 164:129-140.

Nakagawa, S. 2004. A farewell to Bonferroni: the problems of low statistical power and publication bias. Behavioral Ecology 15:1044-1045.

Owen-Smith, R. N. 1988. Megaherbivores: the influence of very large body size on ecology. Cambridge University Press, Cambridge.

Pasenko, M. R. 2012. New remains of Rhynchotherium falconeri (Mammalia, Proboscidea) from the earliest Pleistocene 111 Ranch, Arizona, U.S.A. with a discussion on sexual dimorphism and paleoenvironment of rhynchotheres. Palaeodiversity 5:89-97.

Pérez-Crespo, V. A., J. L. Prado, M. T. Alberdi, J. Arroyo-Cabrales, and E. Johnson. 2016. Diet and habitat for six American Pleistocene proboscidean species using carbon and oxygen stable isotopes. Ameghiniana 53:39-51.

Pianka, E. R. 1976. Competition and niche theory. Pp. 114-141 in R. M. May, ed. Theoretical ecology—principles and applications. Blackwell Scientific, Oxford.

Poole, J. H. 1987. Rutting behavior in African elephants: the phenomenon of musth. Behaviour 102:283-316.

Post, E. 2013. Life history variation and phenology. In E. Post., ed. Ecology of climate change: the importance of biotic interactions. Monographs in Population Biology 52:54-95. Princeton University Press, Princeton, N.J.

Prideaux, G. J., L. K. Ayliffe, L. R. G. DeSantis, B. W. Schubert, P. F. Murray, M. K. Gagan, and T. E. Cerling. 2009. Extinction implications of a chenopod browse diet for a giant Pleistocene kangaroo. Proceedings of the National Academy of Sciences USA 106:11646-11650.

Rabosky, D. L. 2013. Diversity-dependence, ecological speciation, and the role of competition in macroevolution. Annual Review of Ecology, Evolution, and Systematics 44:481-502.

Reguero, M. A., A. M. Candela, and R. N. Alonso. 2007. Biochronology and biostratigraphy of the Uquía formation (Pliocene-early Pleistocene, NW Argentina) and its significance in the great American biotic interchange. Journal of South American Earth Sciences 23:1-16.

Rivals, F., D. Mol, F. Lacombat, A. M. Lister, and G. M. Semprebon. 2015. Resource partitioning and niche separation between mammoths (Mammuthus rumanus and Mammuthus meridionalis) and gomphotheres (Anancus arvernensis) in the Early Pleistocene of Europe. Quaternary International 379:167-170.

Sánchez, B., J. L. Prado, and M. T. Alberdi. 2004. Feeding ecology, dispersal, and extinction of South American Pleistocene gomphotheres (Gomphotheriidae, Proboscidea). Paleobiology 30:146-161.

Sanders, W. J. 2007. Taxonomic review of fossil Proboscidea (Mammalia) from Langebaanweg, South Africa. Transactions of the Royal Society of South Africa 62(1):1-16.

Schluter, D. 2000. Ecological character displacement in adaptive radiation. American Naturalist 156:S4-S16.

Schoener, T. W. 1974. Resource partitioning in ecological communities. Science 185:27-38.

Schoener, T. W. 1982. The controversy over interspecific competition. American Naturalist 70:586-595.

Scott, J. R. 2012. Dental microwear texture analysis of extant African Bovidae. Mammalia 76:157-174.

Scott, R. S., P. S. Ungar, T. S. Bergstrom, C. A. Brown, F. E. Grine, M. F. Teaford, and A. Walker. 2005. Dental microwear texture analysis shows within-species diet variability in fossil hominins. Nature Letters 436:693-695.

Scott R. S., P. S. Ungar, T. S. Bergstrom, C. A. Brown, B. D. Childs, M. F. Teaford, and A. Walker. 2006. Dental microwear texture analysis: technical considerations. Journal of Human Evolution 51:339-349.

Simard, M. A., S. D. Cote, R. B. Weladji, and J. Huot. 2008. Feedback effects of chronic browsing on life-history traits of a large herbivore. Journal of Animal Ecology 77:678-686.

Sinclair, A. R. E. 1975. The resource limitation of trophic levels in tropical grassland ecosystems. Journal of Animal Ecology 44:497-520.

Sinclair, A. R. E., S. Mduma, and J. S. Brashares. 2003. Patterns of predation in a diverse predator-prey system. Nature 425:288-290.

Slotow, R., and G. van Dyk. 2001. Role of delinquent young "orphan" male elephants in high mortality of white rhinoceros in Pilanesberg National Park, South Africa. Koedoe 44(1):85-94.

Smith, G. J., and L. R. G. DeSantis. 2018. Dietary ecology of Pleistocene mammoths and mastodons as inferred from dental microwear textures. Palaeogeography, Palaeoclimatology, Palaeoecology 492:10-25.

Still, C. J., J. A. Berry, G. J. Collatz, and R. S. DeFries. 2003. Global distribution of $C_{3}$ and $C_{4}$ vegetation: carbon cycle implications. Global Biogeochemical Cycles 17:1006.

Stowe, L. G., and J. A. Teeri. 1978. The geographic distribution of $\mathrm{C}_{4}$ species of the Dicotyledonae in relation to climate. American Naturalist 112:609-623.

Teale, C. L., and N. G. Miller. 2012. Mastodon herbivory in midlatitude late-Pleistocene boreal forests of eastern North America. Quaternary Research 78:72-81.

Teeri, J. A., and L. G. Stowe. 1976. Climatic patterns and the distribution of $\mathrm{C}_{4}$ grasses in North America. Oecologia 23:1-12.

Tejada-Lara, J. V., B. J. MacFadden, L. Bermudez, G. Rojas, R. Salas-Gismondi, and J. J. Flynn. 2018. Body mass predicts isotope enrichment in herbivorous mammals. Proceedings of the Royal Society of London B 285:20181020. https://doi.org/10. 1098/rspb.2018.1020.

Tipple, B. J., S. R. Meyers, and M. Pagani. 2010. Carbon isotope ratio of Cenozoic $\mathrm{CO}_{2}$ : a comparative evaluation of available geochemical proxies. Paleoceanography 25:PA3202. https://doi. org $/ 10.1029 / 2009$ PA001851.

Todd, N. E., N. Falco, N. Silva, and C. Sanchez. 2007. Dental microwear variation in complete molars of Loxodonta africana and Elephas maximus. Quaternary International 169-170:192-202.

Ungar, P. S., C. A. Brown, T. S. Bergstrom, and A. Walker. 2003. A quantification of dental microwear by tandem scanning confocal microscopy and scale-sensitive fractal analyses. Scanning 25:185193.

Ungar, P. S., G. Merceron, and R. S. Scott. 2007. Dental microwear texture analysis of Varswater bovids and Early Pliocene paleoenvironments of Langebaanweg, Western Cape Province, South Africa. Journal of Mammalian Evolution 14:163-181.

Ungar, P. S., F. E. Grine, and M. F. Teaford. 2008. Dental microwear and diet of the Plio-Pleistocene hominin Paranthropus boisei. PLoS ONE 3:e2044. https://doi.org/10.1371/journal.pone.0002044.

von Koenigswald, W. 2016. The diversity of mastication patterns in Neogene and Quaternary proboscideans. Palaeontographica Abteilung A 307:1-41.

Wang, S., T. Deng, T. Tang, G. Xie, Y. Zhang, and D. Wang. 2015. Evolution of Protanancus (Proboscidea, Mammalia) in East Asia. Journal of Vertebrate Paleontology 35(1):e881830. https://doi. org/10.1080/02724634.2014.881830.

Webb, S. D. 1974. Chronology of Florida Pleistocene mammals. Pp. 5-31 in S. D. Webb, ed. Pleistocene mammals of Florida. University of Florida Press, Gainesville.

Webb, S. D. 1985. Late Cenozoic mammal dispersals between the Americas. In F. G. Stehil and S. D. Webb, eds. The Great American 
Biotic Interchange. Topics in Geobiology 4:357-386. Springer, Boston, Mass.

Woodburne, M. O. 2010. The Great American Biotic Interchange: dispersals, tectonics, climate, sea level and holding pens. Journal of Mammal Evolution 17:245-264.

Yann, L. T., and L. R. G. DeSantis. 2014. Effects of Pleistocene climates on local environments and dietary behavior of mammals in Florida. Palaeogeography, Palaeoclimatology, Palaeoecology 414:370-381.
Yann, L. T., L. R. G. DeSantis, P. L. Koch, and E. L. Lundelius. 2016. Dietary ecology of Pleistocene camelids: influences of climate, environment, and sympatric taxa. Palaeogeography, Palaeoclimatology, Palaeoecology 461:389-400.

Zhang, H., Y. Wang, C. M. Janis, R. H. Goodall, and M. A. Purnell. 2017. An examination of feeding ecology in Pleistocene proboscideans from southern China (Sinomastodon, Stegodon, Elephas), by means of dental microwear texture analysis. Quaternary International 445:60-70. 